\title{
Verkiesing en predestinasie
}

\author{
GC Velthuysen
}

\section{INLEIDING}

'n Dogma van die kerk ontstaan nie maar sommer vanself nie. Die dogmata is ook nie, in ieder geval nie binne die reformatoriese tradisie, geopenbaarde waarhede nie. Dit val nie uit die lug nie. Dit is nie direkte inplantsels van die Gees nie. Dit is die gevolg van die kerk se worsteling met die Woord; ' $n$ worsteling wat aan die gang gesit word deur die groot vrae waarmee die kerk gekonfronteer word.

Een so ' $n$ vraag is die vraag na die heil - meer bepaald die persoonlike sieleheil. Die vraag is: Wie word gered? Sal ék gered word? Op grond waarvan sal ek gered word? Sal dit op grond van iets in myself gebeur of op grond van iets by God? Die leer van die uitverkiesing of die predestinasie is 'n poging van die kerk om hierdie vraag te beantwoord'.

Dit is grotendeels die rede waarom hierdie kerklike leerstuk in die moderne teologie òf geen òf weinig belangstelling gaande maak. Die vraag na die persoonlike sieleheil figureer naamlik nie meer só sterk as in vroeëre tye nie en volgens die opvatting van sommiges figureer dit hoegenaamd nie meer nie ${ }^{2}$. Daarom hoef dit nie verbasingwekkend te wees dat daar teoloë is wat sê dat die leerstuk maar laat vaar moet word nie $^{3}$.

In die kringe wat só redeneer, geld dit dat die leer van die predestinasie liefs nie meer ' $n$ rol behoort te speel in die verantwoording van ons geloof teenoor die wêreld nie. Konsensus in dié verband, dui daarop dat ' $n$ ander leer in die huidige omstandighede na vore gestoot behoort te word - dié naamlik van die algemene heilswil van God; dat God 'n God is "wat wil hê dat alle mense gered moet word en tot kennis van die waarheid kom" (1 Tim 2:4).

Dit wat betref die situasie rondom die predestinasieleer. Vanuit die perspektief van die gereformeerde ortodoksie sou gesê kon word dat die Armenianisme, in een of ander vorm, en altans vir die huidige, die oorwinning behaal het. En dit was natuurlik juis om die Armenianisme te kelder, dat die Reformasie sy indringendste uitleg van die leer van die verkiesing te Dordrecht opgestel het. Dit was 
bedoel om die laaste en finale woord oor hierdie saak te spreek. Maar uiteindelik is dit deur elke reformatoriese teoloog van betekenis verwerp. Dit, terwyl die sáák van goddelike verkiesing deur 'n teoloog van die status van Karl Barth, aangedui word as die "hele evangelie" en deur sy opvolger Ott as die "unaufgebbarer Punkt"5.

Waarom?

Hierop moet 'n gekwalifiseerde antwoord gewaag word. Geen teoloog van betekenis en van wie se mening mens kennis sou wou neem, sou ooit so ver gaan as om die geloof in die verkiesende God prys te gee nie. Dit sou beteken dat die Bybelse getuienis in dié verband verontagsaam word en dat daar gevolglik dus nie meer sprake van die God van die Bybel is nie. Dat God kies, in vryheid en in liefde, is 'n waarheid wat nie losgelaat durf word nie. En wat, moet bygesê word, ook nie losgelaat is nie. Die beswaar is nie daarteen nie. Die beswaar is wesenlik gerig teen die sogenaamde praedestinatio gemina of dubbele verkiesing; die decretum horribile, soos Calvyn dit genoem, en nogtans verdedig het. Hierdie saak vind sy klassieke formulering in die eerste hoofstuk van die Leerreëls van Dordrecht ${ }^{6}$ :

In Artikel 6 word die aksent gelê op die "ewige besluit" van God: "Dat God sommige in die tyd met die geloof begiftig, ander nie begiftig nie, kom voort uit sy ewige besluit." "Dit is die besluit van verkiesing en verwerping wat in die Woord van God geopenbaar is."

Artikel 7 verintensifiseer dan die saak deur te stel: "Hierdie verkiesing is 'n onveranderlike voorneme van God, waardeur Hy vóór die grondlegging van die wêreld 'n sekere menigte van mense uitverkies het uit die hele menslike geslag ...."

Saamgelees, bring hierdie uitsprake die volgende na vore: God se ewige en onveranderlike wilsbesluit, geneem voor die grondlegging van die wêreld, verkies sommige mense - 'n sekere menigte of bepaalde getal - tot die heil, en verwerp die res, die grootste deel of massa perditionis, tot die verderf.

Die besware is hierteen gerig en kan as volg getabuleer word:

1. Dit verteenwoordig ' $n$ absolute determinisme, wat die verantwoordelikheid van die mens loën. Sodoende maak dit die verkondiging van die Woord en die appèl wat daardeur tot die mens gerig word, kragteloos.

2. Dit is uitdrukking van 'n monistiese sisteem, waar God die outeur word van alle dinge - ook die sonde. 
3. Dit kweek en versterk die hoogmoed by sommige mense, en werp ander weer in vertwyfeling.

4. Die dubbele predestinasie word in ieder geval nêrens in die Bybel geleer nie. Dit is 'n suiwer filosofiese konstruksie.

\section{DOGMENHISTORIESE OORSIG ${ }^{8}$}

2.1 By die vroeë kerkvaders vind ons hoogstens verwysings na die saak van die verkiesing. Dit is bv waar van die geskrifte van Athanasius, Tertullianus en Cyprianus.

Van 'n sistematiese behandeling van ' $n$ uitverkiesingsleer is daar egter nie sprake nie.

2.2 By die kerk van die Ooste is so iets soos predestinasie onbekend . Sedert Justinus verkondig dié kerk konsekwent menslike wilsvryheid. Dit kan egter aangedui word as 'n reaksionêre ontwikkeling. Vanuit die staanspoor het dié kerk naamlik te make gehad met twee deterministiese strominge; die dualistiese sisteem van die Gnostiek (wat leer dat die mens van sy oorsprong af òf tot die lig òf tot die duisternis behoort) en die monistiese sisteem van die Stoa (wat leer dat alle aardse geskiedenis onder die heerskappy van die fatum staan). Dit is te begrype dat die kerk, in sy stryd hierteen, die klem sou laat val op die a-deterministiese aksente in die evangelie.

2.3 Die leer van die predestinasie is ' $n$ produk van die kerk van die Weste - meer bepaaldelik van die teologiese arbeid van Augustinus. Dit rus in sy herontdekking van die Bybelse waarheid van die sola gratia. Die crux van die saak by hom is die ontdekking dat die heil van die mens (en dit beteken vir hom die individuele mens) nie in sy eie hande lê nie, maar in die genade van God. Die heil is iets wat God vry-uit skenk - sonder verdienste by die mens.

Die probleem ontstaan egter wanneer daar, in sy denke oor die genade, ' $n$ klemverskuiwing plaasvind in die rigting van die antropologie. In dié konteks is hy naamlik nie soseer begaan oor die genadedaad van Christus nie, as oor die werking van hierdie genade by die mens. Hy spits sy aandag toe op die verandering (die transformatio) van 'n deur-sonde-verslaafde mens in 'n vry mens. Vanuit hierdie verandering wat in die mens intree, argumenteer hy dan verder in terme van oorsaak en gevolg op soek na die grond daarvan:

As die verandering in die mens uit en uit te danke is aan die genade, moet laasgenoemde teruggevoer word na sy ewige oor- 
sprong. Hierdie ewige oorsprong kan niks anders as die goddelike besluit wees nie.

Hierdeur maak Augustinus die verkiesing los van die openbaring in Jesus Christus. In sy denke is dit uiteindelik niks anders nie as ' $n$ metafisiese postulaat, wat sy oorsprong dank aan 'n kousale beredenering vanuit die ervaring van genade.

2.4 As gevolg van die semi-pelagiaanse teologie van die Middeleeue, had die skolastiek nie veel belangstelling in die predestinasie nie. Dit is 'n leerstuk wat nie binne die teologiese klimaat van dié tydperk inpas nie. Dit is eers weer wanneer die beginsel van sola gratia herontdek word, dat die saak by die reformatore op die voorgrond stoot.

2.5 Die reformasie vertoon, wat hierdie saak betref, nie eenvormig nie, soos uit die volgende blyk:

2.5.1 Luther het aanvanklik, in sy "De servo arbitrio", 'n uiters deterministiese verkiesingsleer op die voetspoor van Augustinus ontwerp. Hy het egter nie daarmee volhard nie. Hy het uiteindelik tot die insig gekom dat hierdie verkiesingsleer spekulatief-natuurlike teologie is en gevolglik het hy hom van die kousale denke van die kerkvader losgemaak. Dit was die gevolg van sy ontdekking van die Bybelse waarheid van die verkiesing in en deur Christus.

Hierdie ontdekking het vir Luther die volgende dubbele implikasie gehad: Die tradisionele predestinasieleer, soos hy dit van Augustinus oorgeneem het, lei nie tot ware kennis van God nie, aangesien dit spekulatief van aard is en die ware leer van die verkiesing is bloot die kennis van die verkiesing in Jesus Christus in die geloof.

2.5.2 Zwingli se leer van die verkiesing kom uit sy "De Providentia". Met die eerste oogopslag word dit al duidelik dat mens hier met spekulatiewe filosofie te make het en nie met Christelike teologie nie. Sy uitgangspunt is naamlik die idee van God as die "summum bonum" en "summum ens". Naas hierdie platoniese idee, plaas hy dan voorts die neo-platoniese dat die kwaad noodsaaklik is, sodat die goeie in sy volle skoonheid kan skitter. Binne hierdie gedagtewêreld is dit maar ' $n$ hanetreetjie na waar $Z$ wingli uiteindelik teregkom: God is dié oorsaak van alles - alles is sy werk - die goeie sowel as die kwade.

Van hieruit ontwikkel hy sy deterministiese predestinasieleer met logiese noodwendigheid. Met Christelike teologie het dit egter maar 
min te make. Dit is eerder aan te dui as rasionele metafisika, half stoïsyns, half neo-platonies.

2.5.3 Wat karakter en oorsprong betref, is die predestinasieleer van Calvyn $^{8}$ heeltemal anders. Hy het immers, meer so as enigeen van die ander hervormers, daarop gestaan om nooit iets te leer wat nie deur die Skrifte geleer word nie. Hy gebruik gevolglik net die Skrif. Hy gebruik dit egter só, vanuit 'n baie bepaalde invalshoek èn met ' $n$ baie bepaalde doel voor oë, dat hy hom skuldig maak aan eensydigheid en teregkom by teenstrydige uitsprake.

Dit is die rede daarvoor dat hy uiteindelik die praedestinatio gemina verdedig het, alhoewel daar nie ondubbelsinnige Skriftuurlike gronde daarvoor bestaan nie.

Dit is egter belangrik om raak te sien met watter doel voor oë hy sy predestinasieleer ontwerp. Hy doen dit omdat dit volgens hom in die eerste plek die lof van God dien en bevorderlik is vir die regverdigheid van hulle wat gered is, deurdat dit hulle tot die besef bring van die mate waarin hulle aan God verplig is. Dit gaan bo alles vir hom daarom om, tot die eer van God, die soewereiniteit van die goddelike genade te verdedig.

Dit blyk veral uit die feit dat hy die praedestinatio gemina aanvanklik nie verdedig het nie. In die eerste uitgawe van die Institusie word dit byvoorbeeld glad nie genoem nie en dit vind net sydelingse vermelding in sy preke en kommentaar. Hier word alle klem gelê op die wonder van die genadige verkiesing in Jesus Christus, wat die sentrale punt in sy teologie is. Dit is immers die enigste manier waarop die sola gratia tot sy reg kom en daarom moet hierdie waarheid met alle mag verdedig word.

Toe die vyande van die sola gratia egter, in 'n poging om dit te diskrediteer, geargumenteer het dat "genade" dan niks anders kan wees as 'n arbitrêre keuse nie, en dat die "sola gratia" dus die leer van die praedestinatio gemina impliseer; het Calvyn die uitdaging aanvaar. As die praedestinatio gemina dan die enigste wyse is waarop die sola gratia staande gehou kan word - moet dit verdedig word.

Vandaar dan dat dit in die tweede uitgawe van die Institusie so sterk aan die bod kom. Vanuit Calvyn se invalshoek en met inagneming van die doel wat hy nastreef, word dit egter heel begryplik. 
2.5.4 Een verdere ontwikkelingstap moet nog in aanmerking geneem word voordat die posisie van Dordrecht behoorlik verstaan kan word:

In die ontwikkelingsgeskiedenis van die teologie, is die leer van die uitverkiesing op een van twee maniere behandel: òf daar is apriori, by die vraag na die verkiesende God begin en op deduktiewe wyse verder gewerk, ò daar is aposteriori by die verkore mens begin en op induktiewe wyse verder gewerk. Die eerste werkwyse lê dan veral nadruk op die vrye soewereiniteit van God en laasgenoemde veral op sy genade.

Eersgenoemde moontlikheid open die weg vir allerlei filosofiese spekulasie oor God en sy wil. Hier word dit naamlik moontlik om die begrip van die Deus nudus te hanteer; om van die verborge God te praat - die God wat nie geopenbaar is nie. Hierteenoor wil die laasgenoemde moontlikheid veral steun op die geopenbaarde wil van God. Die ideaal is om hier niks te sê wat nie deur die Heilige Skrif geleer word nie.

Soos te verwag is, volg die Roomse dogmatiek die eerste weg. Daarom word die verkiesingsleer dáár altyd behandel as deel van die Godsleer. Inhoudelik geld dit in 'n sekere mate ook van Calvyn, maar dit is belangrik om daarop te let dat hy die verkiesing heel aan die einde van die genadeleer behandel; as oorgang tot die eskatologie en ekklesiologie. Uiteindelik val die volle aksent by hom op die genade. Interessant genoeg word die leer van die verkiesing by Zwingli (soos verwag kan word as sy uitgangspunt in aanmerking geneem word) volledig as deel van die Godsleer behandel.

Uiters belangrik egter is die ontwikkeling by Beza. Hý behandel die leer onder Gods "decreta". Hiermee word die verkiesing geheel en al losgemaak van Christus, en uit en uit tuisgebring in die verborge heilswil van God. Hiermee word die Deus nudus opnuut ingevoer in die reformatoriese teologie, en word die deur oopgemaak vir allerlei filosofiese oorwegings wat die reformatore, in teenstelling met die skolastiek, probeer buite hou het.

In hoeverre is sodanige oorwegings toegelaat om oor te neem? Kan dit gesê word dat dit wat hier as 't ware by die agterdeur ingeglip het, sodat die terminologie wat dit meegebring het selfs in die belydenisskrifte gevind kan word, dinge soos die determinisme en daarom die Deïsme en Panteïsme die belydenis ingedra het? 


\section{DIE BELYDENISSKRIFTE}

\subsection{Die Nederlandse Geloofsbelydenis}

Artikel 16 handel oor die ewige verkiesing van God. Dit is besonder interessant om daarop te let dat daar hierin sprake is van ' $n$ sekere dubbelslagtigheid. Alhoewel die woord "dekreet" nie gebruik word nie, is die denkpatroon waarvan hierdie woord ' $n$ aanduiding is, nie vreemd aan die opsteller nie. Die grond van die verkiesing is naamlik God se "eeuwighen ende onverganckelicken raet" (in die Latynse vertaling aangedui as "aeterno et immutabili consilio" en in die Frans as "conseil eternel") 9 . Dit word egter nie losgemaak van Jesus Christus nie, want die verkiesing is 'n verkiesing in "Jesu Christo onsen Heere".

Dit is dus duidelik dat hier nie van 'n verborge heilswil van God sprake is nie. Hier word nie buite-om die openbaring in Jesus Christus gespekuleer nie. Van die Deus nudus is daar hier in ieder geval geen sprake nie.

Ook nie van 'n determinisme nie. Juis omdat vasgehou word aan die verkiesing in Jesus Christus en aan die Bybelse getuienis, vind daar nie 'n ontwikkelng in die rigting van 'n monistiese struktuur plaas nie. Die sonde is die skuld van die mens. Hy stort homself in die verderf. Sy val is net aan homself toe te skryf en nie aan God nie. God betoon sy barmhartigheid daarin dat Hy "uyt enckele goedertierenheyt", diegene wat $\mathrm{Hy}$ in Jesus Christus uitverkies het, uit "dese verderffenisse treckt ende verlost".

Dit moet egter bygesê word dat die formulering van die artikel, soos dit aan ons oorgelewer is, bepaalde vraagstukke onbeantwoord laat. Wat wil die opsteller sê met die formulering dat God mense in Jesus Christus verkies? Wil hy hiermee stel dat Jesus Christus die eintlike Verlore Mens is en dat die wat in Hom glo dus sý verkiesing deelagtig word? Of wil hy sê dat die wat in Jesus Christus sal glo reeds in die ewige raad van God voorverordineer is? Dit word nie uitdruklik gesê nie en is ook nie sonder meer uit die artikel af te lei nie. Dit behoort egter duidelik te wees dat, indien die laasgenoemde verklaring aanvaar word, die determinisme weer helder en duidelik voor ons staan. Daarteenoor, wanneer die eerste verklaringsmoontlikheid aanvaar word, bring dit ons by die standpunt wat Barth so hartstogtelik verdedig het ${ }^{10}$.

In ieder geval lyk dit asof daar geoordeel moet word dat die 
Nederlandse Geloofsbelydenis nie die praedestinatio gemina in deterministiese sin van die woord leer nie.

\subsection{Die Dordtse Leerreëls}

Hier in artikel 6 van die eerste hoofstuk van die Leer, val die woord "dekreet" - alhoewel dan net in die Latynse vertaling: "Quod autem aliqui in tempore fide a Deo donantur, aliqui non donantur, id ab aeterno ipsius decreto provenit." So met die eerste oogopslag, en sonder 'n noukeurige bestudering van die hele teks, mag dit voorkom asof ons hier te make het met die Deus nudus, as voorwaarde vir al die ongewensthede wat alreeds hierbo aangetoon is ${ }^{11}$.

Dit mag ook voorkom asof ons hier te make het met 'n onverbloemde determinisme en ' $n$ klassieke formulering van die praedestinatio gemina. By nadere ondersoek verskyn daar egter enigsins ' $n$ ander beeld.

Kom ons kyk net weer kortliks na die implikasies van die leer van die praedestinatio gemina: Dit veronderstel ' $n$ absolute determinisme. Dit kom daarop neer dat God, voor die grondlegging van die wêreld, sommiges verkies het tot die heil en die ander verwerp het tot die verderf.

Per konsekwensie word menslike verantwoordelikheid dus opgehef. Dit beteken dat die lewe 'n skaakbord word en die mense die pionne wat daarop rondgestoot word - stokke en blokke, soos Luther sou sê. Uiteindelik beteken dit 'n monistiese sisteem waarin God verantwoordelik gehou word vir sonde en kwaad. Is dit wat Dordrecht leer?

Eerste indrukke ten spyt, moet gesê word: nee!

Nêrens is daar ' $n$ aanduiding dat menslike verantwoordelikheid geloën word nie. Ter wille van die konsekwente handhawing van die sola gratia-beginsel, word baie duidelik gestel dat die mens nie verantwoordelik vir sy heil is of kan wees nie - maar hy is ten volle verantwoordelik vir sy verderf. Die "sekere menigte van mense" is uitverkies uit die hele menslike geslag wat deur hulle eie skuld van die eerste regtheid (integritas) in die sonde en verderf geval het. Met ander woorde, die sondeval en die gevolglike verderf van die mens word nie aan die wil van God toegeskryf nie, maar aan die mens self.

Verder word daar ook nie met betrekking tot die verwerping bely dat dit vas besluit was voor die grondlegging van die wêreld - in die sin dat hierdie mense nie anders kón as om te sondig nie. Dit sou 
God, selfs al sou dit net indirek wees, verantwoordelik maak vir die sonde. En dit is iets wat die opstellers van die Leerreëls ten alle koste wou vermy - soos duidelik blyk uit artikel 15: " $\mathrm{Hy}$ (het) besluit om hulle eindelik nie alleen oor die ongeloof nie, maar ook oor al die ander sondes, te veroordeel en ewiglik te straf om sy geregtigheid te openbaar. En dit is die besluit van die verwerping, wat God geensins maak tot die outeur van die sonde nie ('t welck Godslasterlick is te dencken') maar Hom stel tot 'n verskriklike, onberispelike en regverdige regter en wreker daarvan."

Menslike verantwoordelikheid word verder in artikel 16 uitgestippel. Hier word gestel dat diegene wat die lewende geloof en vaste vertroue in hulle harte nog nie gevoel nie, nie mismoedig moet word nie en hulle ook nie onder die verworpenes moet reken nie "maar hulle moet vlytig voortgaan om die middele te gebruik (die middele waardeur God beloof het om alles in ons te werk), vurig verlang na die tyd van oorvloediger genade en dit met eerbied en ootmoed verwag." "Nog minder behoort diegene te skrik wat ernstig begeer om hulle tot God te bekeer, Hom alleen te behaag en van die liggaam van die dood verlos te word; aangesien die barmhartige God beloof het dat Hy die dowwe lamppit nie sal uitblus en die geknakte riet nie sal verbreek nie."

Van ' $n$ dubbele predestinasie, in deterministiese sin van die woord, is daar dus nie direkte sprake nie. Die vraag is of daar miskien tog op indirekte wyse daarvan sprake is. Groot teoloë soos Barth en Brunner het dit daar gevind en mens moet seker respek vir hulle standpunt hê. Ek meen egter om te kan aantoon dat hulle hulle misgis het.

Dit klink asof die Leerreëls werk met 'n Deus nudus en die daarmeegepaardgaande determinisme. Vergelyk met die oog daarop die volgende uitsprake: "Dat God sommige in die tyd met die geloof begiftig, ander nie begiftig nie, kom voort uit sy ewige besluit (decretum)" (artikel 6). "Hierdie verkiesing is 'n onveranderlike voorneme van God, waardeur Hy vóór die grondlegging van die wêreld 'n sekere menigte van mense uitverkies het uit die hele menslike geslag ...." (artikel 7).

Tot op hierdie stadium klink dit nog na 'n suiwer filosofiese projeksie wat met die openbaring in Jesus Christus niks te make het nie. Maar onmiddellik ná die laasgenoemde aanhaling, lees ons die volgende woorde in artikel 7: "Na die vrye welbehae van sy wil het Hy hulle, ... uit louter genade tot die saligheid uitverkies in Chris- 
tus, wat Hy ook van ewigheid af tot ' $n$ middelaar en Hoof van al die uitverkorenes en tot ' $n$ fondament van die saligheid gestel het." Dit is die so noodsaaklike regstelling, wat ons aandag daarop moet vestig dat die vadere miskien hulle toevlug tot filosofiese terminologie geneem het, maar dat hulle nie die Skrifte losgelaat het nie en ook nie vir Christus uit die oog verloor het nie. Daarom het hulle hulle nie skuldig gemaak aan ydele spekulasie nie - maar probeer om die Woord te laat spreek.

Wat egter ongelukkig tot misverstand aanleiding gegee het, was die opstellers se keuse van Skriftuurlike bewysplase. Dié is kennelik nie soseer gekies met die oog op die saak van die verkiesing as sodanig nie - maar om gesag te gee aan die gedagte van die ewige besluit van God, wat aan die wortel van die verkiesing lê. Daarom word daar soveel klem gelê op byvoorbeeld Handelinge 15:18, Romeine 8:30 en Efesiërs 1:4 en 1:11. Dat hierdie verse egter nie daartoe in staat is om die leer van 'n ewige goddelike dekreet in filosofiese sin van die woord te ondersteun nie, word gou duidelik by nadere ondersoek.

Handelinge 15:18 word in artikel 6 aangehaal as bewys daarvoor dat die feit dat God sommiges met die geloof begiftig en ander nie, steun op Sy ewige besluit. Dit is klaarblyklik hoegenaamd nie waarom dit in die besondere teks en Skrifgedeelte gaan nie. Vanuit die konteks beoordeel word dit duidelik dat Jakobus, met 'n wending aan Jesaja 45:21, wil sê dat die heidensending en die totstandbringing van 'n wêreldwye Godsvolk, wat veel meer as oud-Israel omvat, die ewige wil van God is. Die vraag na die persoonlike heil (waarom dit per slot van rekening in die leer van die uitverkiesing gaan) is nie meer hier ter sprake nie - in ieder geval nie direk nie.

Romeine 8:30 word gebruik as steun vir die opvatting dat die wat van ewigheid bestem was vir die saligheid, aan Christus gegee is sodat Hy hulle inderdaad salig kan maak. Dit gaan egter in hierdie hele perikoop om die heilsplan van God, wat daarop neerkom dat die gemeente sal kom tot gelykvormigheid aan die beeld van sy Seun.

Efesiërs 1:11 word eweneens gebruik om as bewys te dien van die feit dat die gawe van die geloof al dan nie steun op 'n ewige dekreet van God in dié verband. Weer eens moet die aandag egter gevestig word op die feit dat dit hier kennelik gaan om die heilsplan van God in Christus.

Maar hierdie feit maak dit al klaar duidelik dat die vadere nie hulle christosentriese standpunt losgelaat het nie en hulle nie kon prysgee 
aan 'n determinisme nie. As gevolg van die ongelukkige keuse ten gunste van die gebruik van die woord "decretum", het die argument van die Leerreëls ' $n$ bepaalde karakter verkry wat die indruk sou kon wek dat ons hier te make het met 'n determinisme - of dan in ieder geval met 'n praedestinatio gemina in deterministiese sin van die woord. Diegene wat die Leerreëls hiervan beskuldig, kyk egter by die ander been waarop die opstellers staan, verby. Menslike verantwoordelikheid word ten volle bely.

\section{WAT IS DIE BEDOELING VAN DIE LEERREËLS}

Dit behoort duidelik te wees dat die opstellers van die Leerreëls eintlik basies net één doel voor oë gehad het, en dit is naamlik die verdediging van die sola gratia-beginsel. Uitgaande van die vraag na die saligheid van die enkeling moes hulle, op grond van hierdie beginsel, uiteindelik by daardie punt teregkom waar gesê word dat dit berus by 'n goddelike besluit. ' $n$ Ander moontlikheid is daar eintlik nie.

Op die vraag na die waarom van persoonlike heil is daar eintlik net twee moontlike antwoorde; òf die mens verdien dit, ò God gee dit. Dit sou aangedui kon word dat binne hierdie twee moontlikhede daar ook nog ruimte is vir allerlei nuanseringe en skakeringe, maar dit is die uiteindelike keuse: verdienste of genade. Hoe daar ook nou verder met woorde gespeel word, heil deur verdienste maak die verwerwing van die heil volledig die verantwoordelikheid van die mens.

Daarteenoor maak heil deur genade God geheel en al daarvoor verantwoordelik. Egter nie so dat menslike verantwoordelikheid totaal ontken word nie - daar word net negatiewe krag daaraan toegeken en nie positiewe verdienstelikheid nie.

Deur die Gees só gelei dat hulle die Skrifte só verstaan het dat die mens sy heil uit en uit aan God in Christus te danke het (vgl veral Ef 2:5-8), kon die reformatoriese vaders nie anders as om hierdie sola gratia-beginsel radikaal deur te trek na elke faset van die evangeliese leer nie.

Wanneer die vraag dan na vore gekom het: Waarom word mnr A salig? moes daar geantwoord word: Dit is die genade van God. Maar waarom juis hy? Waarom word die genade van God aan hom betoon? Dan sou die vadere kon antwoord: Omdat hy glo. Maar waarom glo hy? Omdat hy die Woord gehoor het en die Gees hom hierdeur tot geloof gelei het. Maar waarom het hy die Woord ge- 
hoor? Omdat iemand die Woord verkondig het. Waarom het hy dit verkondig? Omdat God hom die opdrag gegee en gestuur het. Maar, waarom het hý dit gehoor en nie mnr B nie? Die een wat verkondig is nie na mnr $B$ gestuur nie - met ander woorde, die voorwaarde vir geloofsgroei was nooit by mnr B aanwesig nie. Wat is die oorsaak hiervan? Toeval? Nee, antwoord die vadere by Dordrecht die wil van God - sý verkiesing. Dat mnr A salig word, is te danke aan God en aan niks anders nie.

Wat die vadere dus by Dordrecht wou sê, is buitengewoon ernstig. Hulle wil die eer van God beskerm. Hulle wil kampvegters wees vir sy genade en nie verdedigers van moontlike goddelike wispelturigheid nie. Hulle wil Jesus Christus in die middelpunt plaas - Jesus Christus as die Werker van menslike heil - en nie die mens, wat moet antwoord op die appèl van God wat in Jesus Christus gestalte vind nie. Hulle wil God nie degradeer tot 'n onpersoonlike mag wat in soewereine, dog onbetrokke, majesteit besluit oor die mense nie - maar Hom juis bely as die genadige en neerbuigende God wat Hom in Jesus Christus weggee aan die mense.

Wanneer die vraag gestel word of Dordrecht op adekwate wyse aan hierdie geloof uiting gegee het, moet gesê word; ja, ten spyte van 'n paar ongelukkige woordkeuses. Maar dan moet onmiddellik bygevoeg word: adekwaat en genoegsaam ja, maar net vanuit die invalshoek waarvandaan hulle die werklkheid van die goddelike genade benader het. Hulle het dit benader vanuit die vraagstelling na die heil van die individu. Dit kan op baie ander maniere en vanuit talle ander invalshoeke benader word. So byvoorbeeld vanuit dié na die heilswil van God vir die wêreld, of die wil van God ten opsigte van die eventuele saligheid van die heidene.

Dan sal daar méér gesê moet word as wat Dordrecht sê.

Dan sal daar byvoorbeeld meer klem gelê moet word op die verkiesing tot dienslewering en minder op verkiesing tot saligheid (sonder dat die eventuele en werklike saligheid van die individuele heiden uiteindelik aan iets anders as die goddelike verkiesing toegeskryf sal kan word!). Die verantwoordelikheid van die kerk - om in gehoorsaamheid en deur die dra van die Woord aandadig te wees aan die eventuele saligheid van die heidene - sal meer op die voorgrond tree. En daar sal meer gemaak moet word van die wil van God dat almal salig sal word (1 Tim 2:4). Laasgenoemde is so 'n sterk Bybelse motief dat dit nie verontagsaam durf word nie.

Die méér wat in dié verband gesê moet word, sal egter nie die 
uitsprake van Dordrecht ongeldig maak of van die tafel vee nie. Dit sal steeds die antwoord van die kerk, wat aan die reformatoriese tradisie getrou wil bly, moet wees op die vraagstelling waarvoor die sinode van Dordrecht te staan gekom het.

Want nadat die determinisme afgewys is as ' $n$ vreemde filosofiese vergroeisel aan die liggaam van die teologie, moet die teendeel daarvan - totale wilsvryheid - ewe kragdadig afgewys word. Wanneer alles afhanklik gemaak word van die beslissing en wysheid van die mens - word God se verkiesing verskraal tot ' $n$ "vooruit weet", 'n voorkennis van wie sou glo. Dit was die standpunt van Armenius en sy meelopers wat op Dordrecht ten regte afgewys is. Dit staan op semi-Pelagiaanse fondamente en dui die genade aan as verdiende genade.

Sodoende loën dit een van die kernwaarhede van die Skrif en moes die kerk sê wat hy toe gesê het. Dit verhinder hom egter nie om, gegewe 'n veranderde vraagstelling en desgevolglike veranderde invalshoek, meer as toe te sê nie.

\section{IN IEDER GEVAL GEEN GESLOTE SISTEEM NIE}

Die snaakse dualisme waaraan die Leerreëls uitdrukking gee (klemlegging op die verkiesing in Christus en tog terselfdertyd ook op iets wat lyk na 'n filosofiese determinisme) is ' $n$ aanduiding van die dilemma waarvoor die teologie op hierdie punt staan. Die dialektiek raak hier so styf gespan dat dit amper ondraaglik word. Die balans tussen die wil van God en die verantwoordelikheid van die mens is so op die mespunt gebalanseer dat enige konsekwente deurdenking van die een of die ander uiteindelik van die spoor afloop.

Gesien genoemde dialektiek, moet die kerk die vrymoedigheid hê om, wat hierdie saak betref, sy sisteem óóp te hou.

Daar moet nie vanuit bepaalde gegewenhede logiese gevolgtrekkings gemaak word waartoe die Skriftuurlike getuienis geen reg gee nie. Word dit tog gedoen, is die afloop onvermydelik; daar sal òf uitgekom word by 'n volslae determinisme òf by sy teendeel - die apokatastasis of algemene versoening. Nie een van beide is te versoen met die evangelie van Jesus Christus nie en daarom sal kerk en teologie die versoeking om sy sisteem in dié verband te sluit, maar moet weerstaan. 
1 "Die Lehre von der Prädestination in ihren verschiedenen Gestalten (Supralapsarismus, Infralapsarismus) gab Antwort auf die Frage nach dem Heil, und zwar nach dem indivuduellen Seelenheil des Menschen, also auf die Frage Wer wird gerettet? Bin ich gerettet?" (Heinrich Ott, Die Antwort des Glaubens, Kreuz Verlag, Stuttgart-Berlin, 1973², p 199.

2 Só reeds Bonnhoeffer. Vgl die volgende uitspraak: "Ist nicht die individualistische Frage nach dem persönlichen Seelenheil uns allen fast völlig entschwunden? Stehen wir nicht wirklich unter dem Eindruck, dasz es wichtigere Dinge gibt als Diese Frage (vielleicht nicht als diese Sache, aber doch als diese Frage!)? Ich weisz, dasz es ziemlich ungeheuerlich klinkt, dies zu sagen. Aber ist es nicht im Grunde sogar biblisch? Gibt es im Alten Testament die Frage nach dem Seelenheil überhaupt? Ist nicht die Geregtigkeit und das Reich Gottes auf Erden der Mittelpunkt von Allem?" (Widerstand und Ergebung, Kaiser Verlag, München, 1966 (13), p 184.

3 H Ott, a a O, p 204.

4 "Die Gnadewahl ist das ganze Evangelium, das Evangelium in nuce" (Kirchliche Dogmatik, II 2, Evangelischer Verlag, Zollikon - Zurich, 1948, p 13.

5 H Ott, a a O, p 205.

6 Vgl die Kerkboek van die Nederduitsch Hervormde kerk van Afrika, 1958, p 72 en verder.

7 Inligting bekom uit:

7.1 Die Religion in Geschichte und Gegenwart, J C B Mohr (Paul Siebeck), Tübingen, 3 Auglage, 1957.

7.2 Brunner, Emil, Die christliche Lehre von Gott, Zwingli-verlag, Zurich, 1946.

7.3 Polman, A D R, Onze Nederlandsche Geloofsbelijdenis, T Wever-Franeker.

8 Calvin, John, Institutes of Christian Religion, translated by Henry Beveridge, Wm. B Eerdmans Publishing Company, Grand Rapids, Michigan, Volume 2, pp 202-258.

9 Die oorspronklike tekste volgens Bakhuizen van den Brink, J N, De Nederlandse Belijdenisgeschriften, Ton Bolland - Amsterdam, 1976².

10 A a O., pp 1-498.

11 Die gedagte van die absolute ewige dekreet van God, staan op drie pilare, wat aangedui kan word as filosofies beïnvloed:

\section{1 'n Starre Godsbeeld}

Die klassiek-reformatoriese Godsbeeld, soos dit by Calvyn aangetref word, is die van die neerbuigende God - God in sy genadige toenadering tot die mense. Hierteenoor lê die skolastiek klem op die transendensie van God. $\mathrm{Lg}$. Godsbeeld is egter die van die filosowe. Hiervolgens is God aan te dui as die Onbewoë Beweger, die Eerste Oorsaak, die Diepste Grond ens. So 'n God is ' $n$ Deus nudus - 'n God wat buite Christus om optree en handel; 'n God wat ewige dekrete maak, 'n onveranderlike en harde God. Vanuit die openbaring leer ons ' $n$ ander God ken - die Vader van Jesus Christus.

$\mathrm{Hy}$ is die genadige en barmhartige God. Hy is onveranderlik in sy trou, maar nie onveranderlik van besluit nie. Hy hoor immers die gebed en Hy ontferm Hom oor dié wat Hom vrees.

\section{2 'n Verkeerde kousaliteitsbegrip}

Die begeerte by die hervormers om alle tekens van 'n sunergisme te vermy, en om die sola gratia ten alle koste te handhaaf, het in die gereformeerde skolastiek daartoe gelei dat die mens verstaan is as die blote objek van die goddelike genade en die geloof gesien is as die blote gevolg van die werking van die genade. Dit word as uit-en-uit kousale verhouding gesien: God is die oorsaak - 
die geloof die gevolg. Hierdie verkeerde siening van die geloof het uiteindelik invloed uitgeoefen op die begrip van die verkiesing; gaandeweg het "electio" begin verander in "determinatio".

11.3 'n Verkeerde ewigheidsbegrip

Wanneer die verkiesing verstaan word as 'n besluit van God voor alle tye (dws. voor die tyd), word dit uit die sfeer van die persoonlike verhouding geneem. Die Bybelse begrip van tyd hou egter baie noue verband met die begrip van die persoonlike. Dit is daarom radikaal anders as die fisiese en wiskundige begrip van tyd. In die denke van die Bybelskrywers is die tyd altyd menslike tyd, historiese tyd, tyd van beslissing (Brunner). Hierdie beslissing is dié in Jesus Christus. In die sfeer van die geloof word die tyd gevul met die spanning van die ewigheid. In die geloof deel ons dus reeds in die ewigheid. In die geloof is tyd dus nie die teendeel van die ewigheid nie, maar het deel daaraan.

Daarom is die ewige verkiesing iets heeltemal anders as ' $n$ besluit wat baie lank gelede ten opsigte van elke afsonderlike mens geneem is. Dit is veel eerder dit wat in Jesus Christus ' $n$ gebeurtenis in die tyd word. Dit beteken dat God se liefdeswoord, wat my hier en nou in Jesus Christus ontmoet, my vanuit die ewigheid bereik - dat dit voor my bestaan het en besluit is en dat dit my bestaan moontlik maak. Daarom maak dit nie die menslike bestaan en besluit futiel nie en word die menslike beslissing nie gedegradeer tot ' $n$ illusie nie. 